\title{
SCAPING THE BAJAU THROUGH RITUALS AND CELEBRATIONS IN MARITIME OF MALAYSIA AND THE PHILIPPINES
}

\author{
Hanafi Hussin ${ }^{1}$ and Judeth John Baptist ${ }^{2}$ \\ ${ }^{1}$ Department of Southeast Asian Studies, Faculty of Arts and Social Sciences, \\ Institute of Ocean and Earth Sciences (IOES) \\ Social Advancement \& Happiness Research Cluster \\ University of Malaya \\ 2Independent Scholar \\ (hanafih@um.edu.my, judeth.baptist@sabah.gov.my) \\ DOI: https://doi.org/10.22452/brj.sp2019no1.2
}

\begin{abstract}
Lexically, the word scape is referred to a specific analogical view of something visible to people on the ground. In cultural studies, the scape is interpreted beyond a physical and visible context. It is a blend of both tangible and intangible cultural dimensions such as music/soundscape and dancescape. Bajau-Sama communities on the East Coast of Sabah and Bajau Laut in the Philippines live harmoniously in an environment where the living of the spiritual world is significant and vital. Balancing the people in the physical and spiritual world through rituals as efficacies are to be performed according to the bonding through inheritance of heirloom for many generations. All scheduled ritual performances not only are fulfilling the agreement between the physical and the spiritual world, but it also produces sounds and movements which add to the scapes of these communities' world. Music and dance performances in these rituals are identic to the soundscape and dancescape with many types of specific ritual music and dances, i.e., igal soundscape and igal dancescape. The male and female music sounds, dance movements, and phrases in different kind of rituals are not only fulfilling the "manifest functions" but also signify the "latent functions". Based on the observations of a few rituals among these communities in Semporna, Sabah and Sitangkai Island, Philippines; this paper analyses the scapes of Bajau as both tangible and intangible. This paper will also discuss the significance of these scapes in sustaining Bajau-Sama identity of these areas particularly to Malaysia and the Philippines.
\end{abstract}

Keywords: Bajau-Sama, ritual, celebrations, igal music and dance, identity, Malaysia, the Philippines 


\section{Introduction}

In some communities, music plays different important roles. It works as an agent of social service and entertains all kinds of people. It helps to unify the communities and works as an agent of socialization. It has a great impact on emotional and physical developments. And, in some cases, music and dance together strengthen social relations that no other tool could do it (Lull, 1985) and also could boosting inter-ethnic relations (Tassanawongwara \& Hussin, 2019, pp. 1-18). Music, sounds, and dances often create link between the seen and the unseen (spiritual) world in the ritual performances (Blacking, 1985). Sama-Bajau communities on the East Coast of Sabah in Malaysia and Bajau Laut in the Philippines living harmoniously with the spiritual whose presence is liked and favoured for uncountable benefits to the communities. However, spiritual worlds is also deemed dangerous if the communities did not make certain arrangements; thus, in order to balance the two worlds (physical and spiritual), Sama-Bajau perform ritual performances not only are fulfilling the agreement between the physical and the spiritual worlds, but they believe that through igal-soundscape and igal-dancescape they create an environment that pleases the spirits so that life will always be balanced (Hussin, John Baptist, \& Pugh-Kitingan, 2018, pp. 181-204). There are various dimensions to such dancescape and sound/musicscape among Sama-Bajau but unknown to the world. This article, therefore, would like to those investigate those manifest and latent functions and dimensions dance and music/soundscapes of Sama-Bajau communities especially the significance of these scapes in sustaining Sama-Bajau identity of these areas particularly to Malaysia and the Philippines.

\section{Scape - literature review}

Lexically, the term or suffix 'scape' is defined and interpreted referring to a specific analogical view of something visible to people on the ground. In cultural studies, the scape is interpreted beyond a physical and visible context. It is a blend of both tangible and intangible cultural dimensions such as music/soundscape and dancescape. The scape has been applied in different dimensions and contexts in cultural, anthropological, political, sociological, political, media and other studies. Some of the examples of the use of suffix scape are: servicescape (Bitner, 1992), social-scape (Albrow, 1997), ideoscape, mediascape, technoscape, financescape and ethnoscape (Appadurai, 1996), musicscape (Oakes, 2000), sports-scape (Wheaton, 2004), lifescape, moodscape and colorscape (Choy, 2006), heritage-scape (Di Giovine, 2009), dancescape (Szeto, 2010), and diseasescape (Harper \& Armelagos, 2010).

The suffix is used in two contexts: 1) The local contexts such as Bitner's (1992) servicescape and Oakes' musicscape and also in a local and global context or connection between the local and global. In the local context, the landscape (or scape) 
are local elements influencing the individuals in the given social and cultural circumstances physical music environment influencing customers and workers; 2) In the local-global context, the scape is so big and wider that include debate of ideologies, transnational materials, values and cultures (Oakes, 2000, Appadurai, 1990; Albrow, 1997; Smith, 1994).

In the context of the complexity of the global market - which is linked with the disjunction of politics, culture and economy - Appadurai (1990) had offered five conceptual scapes of the global economy and culture; which he called ideoscape, mediascape, technoscape, financescape and ethnoscape. Appadurai used the suffix scape to explain that these are cultural views (fluid imaginations), depend on the status of the individual who views or experience it, and these cultural views are facets and realities of the world, but these keep changing (in other words, these are fluid) (Appadurai, 1990). He claimed that all scapes are changing so cannot look at these from a single point of view but from various angles and directions which could be linguistic, historical and political. He also maintained that all the scapes (also call them landscapes) worked as building blocks of imagined worlds or imagined social practices. Later on, Albrow (1997) added another scape into Appadurai's scheme of scapes, socioscape. Albrow used the term to argue (but supporting Appadurai) that there were not fixed communities but fluid, deteriorating and changing communities under the influence of globalisation. Appadurai does not overtly overrule the possibility of static and stable communities, but their survival is short because the continuous process of globalization influences them. However, some nations, communities and cultures, attempt to keep their ritualistic and social practices constant in the stable shape.

\section{Definitions}

Oakes (2000) took musicscape from the Bitner's (1992) model of the servicescape, in which musicscape is presented as one of the physical environmental (scent, air, quality and temperature) conditions that affect customers and employees' attitude in the job related environmental perspective. Bitner used the model to investigate a broader area of non-verbal communication and interaction within a service environment and presented how environmental aspects could influence the emotional, physiological and emotional responses of workers and customers. Oakes' (2000) musicscape visual model has harmony, compositional tempo, volume and genre (i.e. jazz, classical and popular). The composition of factors in the model could also be a liking of the customers (Oakes \& North, 2008). For Porteous and Mastin (1985), the soundscape is "the overall sonic environment of an area, from a room to a region" (p. 169). Schulte-Fortkamp and Kang (2013) added that soundscape is "an environment of sound with an emphasis on the way it is perceived an understood by the individual, or by a society". In also means that soundscape is a combination of 
sounds that come from a social and creative environment. For Johnson (2011), dancescape as a combination of interconnected dance bits. There are interlinked in various ways that include geographic nearness, membership networks, or influence.

\section{Dancescape and musicscape}

In this paper, we draw inspiration from the term of scape and apply it to social practices of dance and music among Bajau-Sama communities on the East Coast of Sabah and Bajau Laut in the Philippines. The terms of musicscape and dancescape are also used in transnational, transcultural and fluid contexts (as Appadurai has envisaged) as well as in the static context with the local communities' practices and rituals. In researches, the dancescape and musicscape are not used together. Scholars have addressed these two domains separately, but dancescape and musicscape among some communities such as Sama-Bajau are part and parcel. In dancescape, bodies, knowledge, expertise, ideas flow in continuation, and also keep changing; however, the local dance practices are not only influenced by the transnational knowledge and practices performed by international dancer, but the international dancers also participate and learn from the local dancers (Wong, 2011). The local companies while performing dances across the globe turn out to be transnational dancescape (Szeto, 2010). There is also the argument that the local materials and its forms such as fashions, music and talents flow to the international scape. Singapore street dance, community's costume and fashion are exported which are often considered unique and colourful (Wong, 2011). Dancescapes' are an interrelated discourse of dance and these scapes share a common ground and provide space for cultural difference in the description of dance in the historical context (Szeto, 2010).

In Bourdieu's theory of social practice, "dance is a cultural practice" (Papakostas, 2015) and it is a source "through which the community manages its past and present, is reconstituted at a symbolic level and incorporates elements of contemporary developments into its traditions in a dynamic manner" (Nitsiakos, 2003, cited in Papakostas, 2015). Dance is not a stable cultural practice. It has unstable and changing characteristics and in unique processes, it is "historically predetermined and subject to social and political manipulations and negotiations" (Nitsiakos, 2003, cited in Papakostas, 2015). In this view, the examination of dance has to not only to take place with a certain territory, space or locality but it is constituted in the result of a historical process which has passed through various social and economic conditions and power relations exercised in a given moment (Papakostas, 2015). At the given time, dance is not just a product but process (Cowan, 1990) and linked to cultural and ethnic identity. It is also a representation of the group/s identity. Thus, dance enables us to know the linkages between groups, the social practices, and the strategies used by the groups (Papakostas, 2015). However, in a given time and space, when dance is considered as dancescape, it reveals the 
specific details of body movements in the space, the interface and relation of bodies and sounds which together are seen moving on the floor, transmitting energy, feelings, and emotions between the participants of the seen and unseen worlds. Dancescapes contains memories (the past) and ritualistic practices but hardly allow changing patterns of dance movement unless the social context has changed.

Within the musicscape, the role of the soundscape is extremely important in ritual performances or any act of social practice that entails sounds. In studies of music, the visual art has received great attention, but sounds remained at the outer edge. Within the music, sounds have great importance in cultural landscapes. For Smith (1994), musicscapes are created or generated in a specific context. Thus, these must be listened or understood in the given context. He added, "music has the power to evoke a sense of space different from that evoked by sight...sound, especially in the form of music, has a social and political significance which, it could be heard, might influence, change or enrich the interpretation of particular scenes" (p. 234). The music sound could explain the qualities and characteristics of relationships between people and also to the environment (Shepherd, 1991). Smith (1994) argued that in the study of musicology and social geography, the soundscape is indetachable from social landscape and music (aural) is extremely significant in the geographical imagination.

\section{Sacredscape and Secularcape of Bajau/Sama-Tangible and Intangible}

The beliefs and traditions of the Bajau community have shaped physical scapes and cultural scapes (intangible) in Semporna, Sabah and Sitangkai, Philippines. The manifestation of traditional belief in by series of rituals performed either quarterly, annually or any time of the year according to the traditional calendar forming the sacred physical scape and intangible scape. The ritual manifestations mainly performed by the older generation of the community due to make belief practices harmonizing and balancing the living in the physical world and the spiritual world. Meanwhile, among the younger generations of Bajau continue to practice the ancestors' tradition as a heritage by learning the traditional dance and music as a cultural activity, performed at the event in the community such as wedding and culture and arts programs such as official occasions and festivals. There are also members of the Bajau community practising their traditional art as a source of livelihood, especially in tourism. These phenomena created a dynamic cultural scape of the Bajau community in the Bajau area and outside. These physical and intangible cultural scape shows the secular scapes embed with traditional values and function as the social obligation, entertainment and identity maintenance and enhancement.

The Bajau of Semporna and Sitangkai perform various traditional healing ritual and scheduled rituals including mag-bekelamat, magpa-igal Jin, magpaiibahau, etc. to honour the ancestors for newly harvested rice, mag-duwata kabusungan 
healing ceremonies, mag-busung rituals to ward off curses from the ancestors, magkelamat exorcisms or healing rituals for very serious illness, mag-jikil Islamic prayer ceremonies, and others. In some cases, depending on the context, some of these may be performed in sequence or as overlapping components in a single ritual event (Pugh-Kitingan, John Baptist, \& Hussin, 2012, pp. 98-1002).

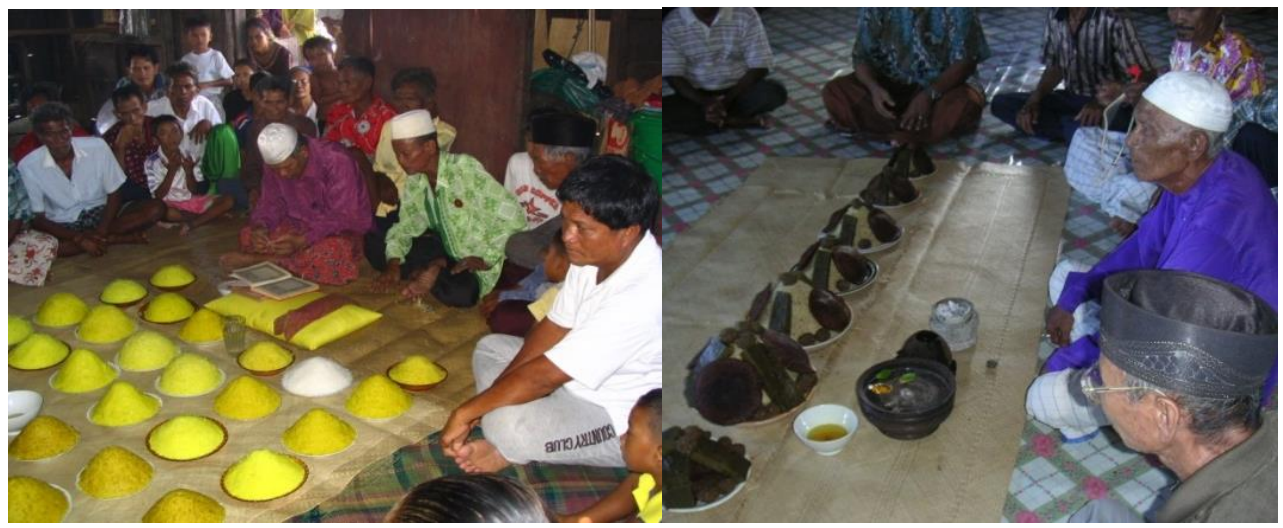

Figure 1: Magpaii-bahau of Bajau Laut, Kampung Bangau-Bangau, Semporna, Sabah (left) and Magpaii-Magduwata of Bajau Kubang, Kampung Kabimbangan, Bumbum Island, Semporna, Sabah (right)

(Source: Hanafi Hussin, fieldwork, 2004, 2005.)

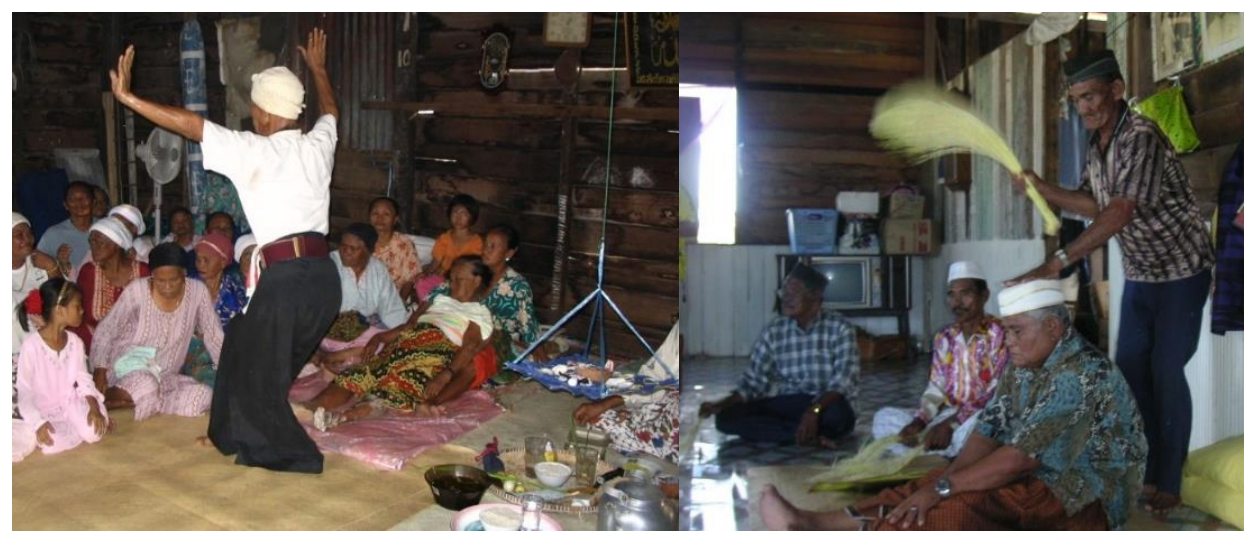

Figure 2: Healing Ritual-Mag-kelamat (left) and Mag-duwata (right) of Bajau Kubang of Semporna, Sabah

(Source: Hanafi Hussin, fieldwork, 2004, 2005.)

As the healing ritual and scheduled ritual colouring the sacred scapes, physical and intangible, there are many inherit sacred cultural activities embed in those rituals. The paraphernalia used in those rituals signifying the manifestation of the rituals and marked the Bajau sacred scapes being form heard and seen. 
Langkapan, kalangkang and others marked the sacred physical scapes of the Bajau throughout the year. The Bajau Kubang community of Semporna performs a healing ritual like magkelamat, and annual ritual like magpaii-bahau with few different terms like magkok-taun, magduwata, etc. to hold the annual new rice offering ceremonies of magpaii bahau (offering of newly harvested hill rice). Either return to Kabimbangan Island or Omadal Island annually, the Bajau community without fail should perform this ritual.

This event will add more variety to the Bajau landscape with ritual paraphernalia especially langkapan, sambulayang, tipas-tipas, etc. Failure to hold this annual new rice offering ceremonies over two annual cycles believed will contribute to the 'imbalance of spiritual energies' in the household of the family who inherits the langkapan. To revive the balancing of the relationship, the healing rituals of magduwata need to be performed along with magpaii-bahau. Therefore, magduwata healing ritual conducted to placate spirits of ancestors that were assumed to have caused illness to the members of the household, in particular, the bearer of the langkapan.

Another sacred cultural scape can be observed from the ritual complexes of the Bajau community is the wearing of proper traditional cloth among the healers and the spirit medium bearers in the ritual space and sometime in the village. The healer (mag-kalamat) and the spirit bearer (magduwata) either a man or a woman dons the ancestral costume of black or yellow trousers (saluar ruwata) and black shirt (badjud ruwata), with a headcloth (porong) and sarong (tadjing) worn across the torso from the left shoulder. A woman spirit medium usually wears a yellow headcloth and a long yellow scarf over one shoulder. Holding a yellow cloth (saputangan) in the right hand and a frond of areca palm (bagaybay or bagaibai) in the left, the dancer enters a state of conscious trance at the sound of the tagunggu' and begins dancing in time to the music, adding more scape to the village which will be discussed in the next topic.

\section{Dancescape and musicscape of sacred}

Within the Bajau community share commonalities in the way, dancers are performed based the different options of musical tunes during the ritual ceremony of the offering of newly harvested rice (magpaibahau or magduwata) and to please the ancestral spirits (magpa-igal) or offerings for sea-spirits (pagkanduli). These sacred dances and music are giving more colour of sacred activities and communal gatherings which add more sacred scapes to few determined geographical spaces. Ritual healing ceremonies are linked with specific dance performance (mag-igal) and playing of specific music tunes (titik) through the kulintang music that is usually called as tagunggu' which is consisted of a set of graduated pot gongs, tambul (double-headed snare drum), and tawag (large hanging gong) or agung (two big 
hanging gongs). The tunes (titik) played during the ritual healing ceremonies are intended for the spirit bearer (jin)- the male spirit bearer (jin lella) or female spirit bearer (jin denda) represent the jin. arer The tunes (titik) may also signify the places where these events take place such as titik lellang for the magduwata ritual amongst Bajau Kubang in Semporna (East Malaysia) or titik limbayan for the pagkanduli ritual of the Sama-Dilaut in Sitangkai (the Southern Philippines). Likewise, the tunes have gender specific context; these are linked to the gender of the spirit-bearers, for instance, titik limbayan for female spirit-bearer (jin denda) and titik lellang for the male spirit bearer (jin lella).. In other words, musical tunes of the tagunggu' or kulintang ensemble played during the ritual healing ceremonies are identified with the gender of the spirit (Jin), which have entered into the spirit bearers bodies, hence a male spirit bearing body may either become a male spirit (jin lella) or a female spirit (jin denda). As an extension to the markers of gendering bodies, dance or igal within the context of these rituals are also identified and named after the tunes, such as igal lellang and igal limbayan respectively (Nor \& Hussin, 2012a, p. 104).

\section{Sacred musicscape of Bajau-Sama}

Magtagunggu' or music making are part and parcel of dance (mag igal). Therefore, the ritual musical collections of magtagunggu' subsumes dances (igal) and musical pieces (titik), which are generally performed for non-ritual activities and also at the time of specific dance styles and ritual pieces.

Table 1: Tunes (titik) in the rituals of Magduwata, Magpaigal and Pagkanduli

\begin{tabular}{|c|c|c|c|}
\hline Type of & Magduwata & Magpaigal & Pagkanduli \\
\hline $\begin{array}{l}\text { Tunes for Female } \\
\text { Jin (Jin Denda) }\end{array}$ & Titik limbayan & Titik limbayan & Titik limbayan \\
\hline \multirow{2}{*}{$\begin{array}{l}\text { Tunes for Male } \\
\text { Jin (Jin Lella) }\end{array}$} & & Titik Jin & Titik Jin \\
\hline & $\begin{array}{l}\text { Titik Lellang } \\
\text { As a final piece, titik } \\
\text { tabawan is played to the } \\
\text { accompanying of igal } \\
\text { tabawan. } \\
\text { Both are often referred to } \\
\text { as titik duwata by the } \\
\text { community. } \\
\text { Other titik - titik tabawan, } \\
\text { titik jampi or titik jaupi, titik } \\
\text { lakkas-lakkas (is similar to } \\
\text { titik tabawan from Tabawan } \\
\text { island and titiklubak-lubak }\end{array}$ & $\begin{array}{l}\text { Titik Lellang } \\
\text { Titik lubak-lubak marks the } \\
\text { end of magpa-igal and is } \\
\text { played for the leader of } \\
\text { the male spirit bearer. } \\
\text { Titik limbayan, titik lellang } \\
\text { and titik tabawan are } \\
\text { played as final pieces. }\end{array}$ & Titik Lellang \\
\hline
\end{tabular}


Source: Hanafi Hussin, fieldwork, 2004, 2005, 2008.

The musical tunes of titik lellang, titik tabawan and titik limbayan are played with corresponding dancing styles known as igal limbayan, igal lellang and igal tabawan as observed in magpai-bahau/magduwata ritual of Bajau Kubang in Kampung Kabimbangan, Semporna, Sabah, 2005. In the case of Bajau Laut of Bangau-Bangau, Titik Tabawan is always called as Titik Lubak-Lubak, which is used in the Magpaigal ritual. Only titik limbayan and titik lellang, are played for the dances of igal lellang and igal limbayan. Thesemusic tunes are specific for the spirit mediums (jins). The two music tunes are also for the ancestors and are called as titik duwata (Nor \& Hussin, 2011). Besides, additional tunes are played to invite ancestral spirits to the living world. These tunes are titik tagna (introductory piece), titik jampi or titik jaupi (incantations for the ancestors), and titik lakkas-lakkas (is similar to titik tabawan from Tabawan island and titik lubak-lubak-literally means to play fast and fast-played amongst the Tausug). In the magpa-igal and pagkanduli rituals of Sama Dilaut in Sitangkai (the Southern Philippines) and Bangau-Bangau of Semporna (Sabah, Malaysia), only three tunes (titik) are known. These tunes are the titik jin, titik limbayan for jin denda (female spirit bearer) and titik lellang for jin lella (male spirit bearer as can be seen in Table 1 .

Sacred soundscape and musicscape among Bajau Laut community are more vibrant as the music making among this community is frequently played either in Semporna, Sabah or Sitangkai, Southern Philippines in the magpa-igal ritual. Pagkanduli ritual, etc. which magpa-igal ritual performed quarterly by the family members. It is common in the rituals of magpa-igal and pagkanduli that titik limbayan is played by the tagunggu'/kulintang ensemble in the beginning repertoire of female spirit bearers (jin denda) who perform the igal limbayan dance. The dance is followed by titik jin for the dance of igal jin lella (he male spirit bearers); after that, the tunes of titik tabawan and titik lubak-lubak are played for female spirit bearers who perform dance of the igal lellang (Hussin \& Santamaria, 2008). Therefore, tunes of the tagunggu'/kulintang correspond to gender specific dances of the spirit bearers. The male tunes of titik lellang for male dancers (and spirit bearers) are linked to the thunderous gongs and beating of the drums to facilitate and encourage trance dancing during the ritual peak performance. In a trance state, the spirit bearers (jin) dance energetically and constantly stamping their feet on the floor, which echoes the energetic movements of the male spirit in the body of the male spirit bearers (John Baptist \& Regis, 2012).

\section{Sacred Dancescape of Bajau-Sama}

As sacred soundscape and musicscape fill-up with the variety of gendered music or titik, most of them accompanied by the sacred dance mainly performed by the male and female jin bearers which mainly generally called as igal, igal jin denda (dance of female jin) and igal jin lella (male jin dance) (see Table 2). Along with the tune of titik 
limbayan, the dance of the female spirit bearer is performed, and the dance is called as igal limbayan. In the slow and languid dance, the body cologne is sprinkled onto the female spirit bearer to induce her to come into the body of the male dancer. A burst of quick movements of the body marks the unification of spirit guides into the body of the male spirit bearer. Likewise, processes are also witnessed in the dance performed by the male spirit bearer (igal jin lella) when titik lellang (for Bajau Laut in Bangau-Bangau, Semporna, Sabah) or titik jin (for Bajau Laut/Sama DiLaut of Sitangkai) are played during magpa-igal ritual dance.

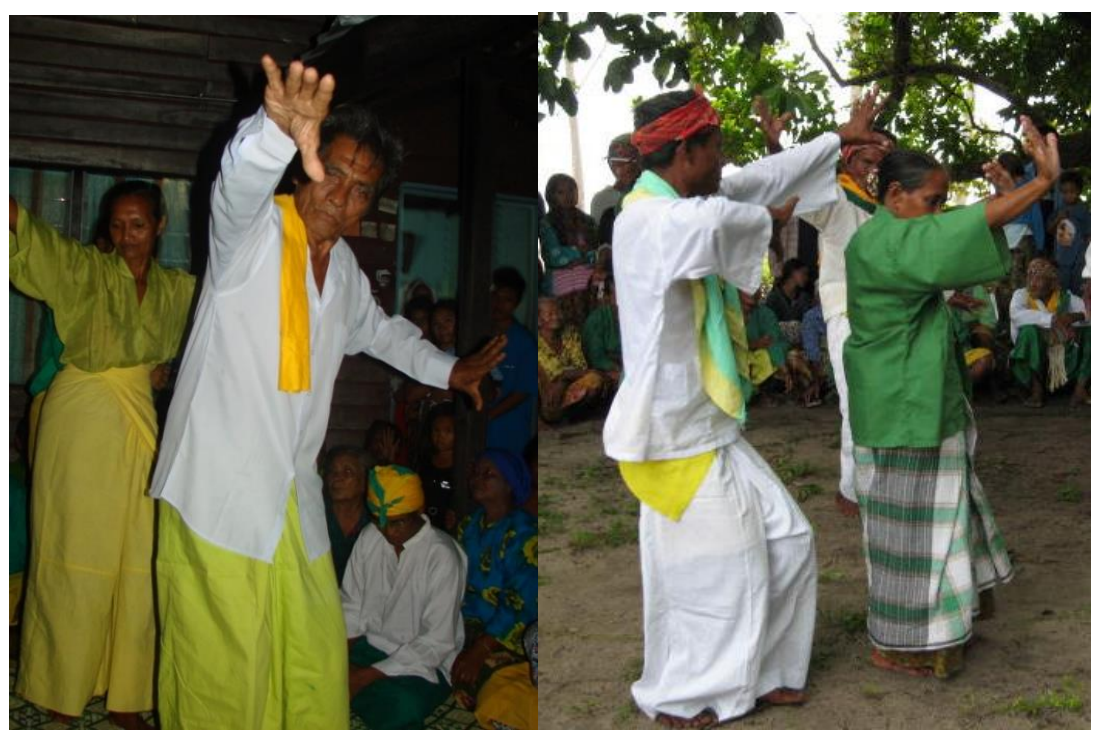

Figure 3: Magpaigal Jin of Bajau Laut of Bangau-Bangau, Semporna, Sabah (left) and Igal by Jin Lella and Jin Denda in Pagkanduli Ritual of Sama Dilaut, Sitangkai Island, Southern Philippines

(Photo: Judeth John Baptist, Sabah Museum [left] \& Hanafi Hussin, fieldwork, 2008 [right].)

The same process is also observed in the dance of the Pagkanduli ritual. As the igal jin denda dance, it is said that the female bansa (spirit guide) watches the performance being offered to them. If the music is particularly good especially during the times with a fast rhythm, the bansa apparently joins and dances together with the human performers. It is also believed that the bansa occasionally show their pleasure by entering the igal jin denda's body through a central spot of the head called as the imbun-imbunan (Hussin \& Santamaria, 2008, p. 163). However, they temporarily residence in the body of the igal jin denda who often felt weary and some pain. For releasing the bansa from their bodies, the igal jin should recite sacred words or phrases (kata-kata). This recitation may come in the form of chanting or incantation (Hussin \& Santamaria, 2008, p. 163). 
The similar happened to the sacred dancescape of Bajau Kubang. Those individuals having the strongest feelings to fall into a trance are encouraged to perform the role of dancing spirit bearer.

Table 2: Dance (Igal) repertoire in the rituals of Magduwata, Magpaigal and Pagkanduli

\begin{tabular}{|c|c|c|c|}
\hline & Magduwata & Magpaigal & Pagkanduli \\
\hline $\begin{array}{l}\text { Dance for Female } \\
\text { Jin (Jin Denda) }\end{array}$ & Igal Limbayan & Igal Limbayan & Igal Limbayan \\
\hline \multirow{3}{*}{$\begin{array}{l}\text { Dance for Male Jin } \\
\text { (Jin Lella) }\end{array}$} & Igal Jin & Igal Jin & Igal Jin \\
\hline & $\begin{array}{l}\text { Igal Tabawan - a finale } \\
\text { dance piece of the } \\
\text { magduwata ritual } \\
\text { accompanied by titik } \\
\text { tabawan. }\end{array}$ & Igal Lellang & Igal Lellang \\
\hline & $\begin{array}{l}\text { Titik Tabawan- played } \\
\text { for everyone to dance, } \\
\text { which includes all the } \\
\text { spirit bearers i.e. Jin Lella } \\
\text { and Jin Denda as well as } \\
\text { participants and } \\
\text { observers of the } \\
\text { magduwata ritual } \\
\text { outsiders at the end of } \\
\text { the ritual event. }\end{array}$ & $\begin{array}{l}\text { Titik Tabawan- played } \\
\text { in the middle of the } \\
\text { ritual enabling Jin } \\
\text { Denda and Jin Lella to } \\
\text { dance together at the } \\
\text { same time. }\end{array}$ & $\begin{array}{l}\text { Titik Tabawan- } \\
\text { played in the } \\
\text { middle of the ritual } \\
\text { enabling Jin Denda } \\
\text { and Jin Lella to } \\
\text { dance together at } \\
\text { the same time. }\end{array}$ \\
\hline
\end{tabular}

Source: Hanafi Hussin, fieldwork, 2005, 2008, 2010.

Like humans, jins are gender specific. Therefore, possession by male or female $j i n$ is recognized through the playing of specific music tunes (titik). Titik limbayan is lined with the possession by female jin, and Titik Lellang is linked with male jin A spirit medium who dances the igal-jin holds a handkerchief (jimpau) in his or her right hand and areca palm fronds in his or her left hand. In a Malay myth, palm fronds from the areca plant are viewed as food for roaming spirits. It is quite possible that the same processes is followed among the Bajau Kubang. Once the jin fell into a trance, a member of the family places a handkerchief on his or her shoulder to confirm that the dance is performed in a trance. It is during the igal-jin dance that ritual healing takes place.

Dance and music (tunes) in the rituals have become necessary for the participants; these are found, virtuous and profound to the magduwata ritual. It is the peak of festive moments in the intense rites of the given ritual, cathartic and salutary, the former to ill health, while the latter to the spirits of the ancestors. All family members also take part at the end of the trance-dancing (igal-jin) and ritual healing. 
They dance the mag-igal for the whole day until the sun to set. At this moment, the dance is turned a social-dancing which is usually performed in a linear formation around the living quarters that was considered a sacred healing space (Nor \& Hussin, 2012b, pp. 143-148).

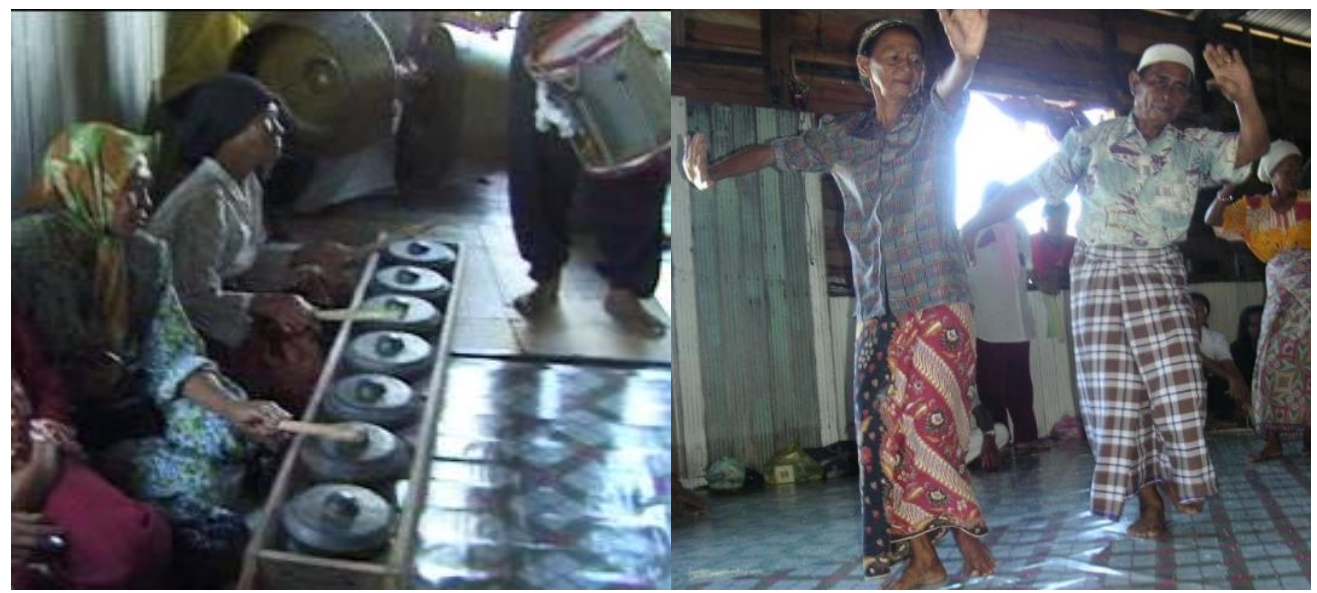

Figure 4: Magtagunggu' (music)-left, Mag-igal (dancing) right in the Maduwata Ritual of Bajau Kubang of Semporna, Sabah

(Source: Hanafi Hussin, fieldwork, 2005.)

\section{Dancescape and musicscape of social and entertainment phenomena}

Apart from its role as a manifestation of spirit possession, igal also occurs without trance as a form of celebration in other traditional contexts which are also enriching the soundscape, musicscape, dancescape and also the physical and cultural landscapes of the Bajau in both countries. Important social gatherings, such as weddings and circumcision ceremonies (berkhatan) as well as the Maulud Nabi in remembrance of the birth of Islam's prophet Mohamed and any other significant Islamic events, are celebrated with igal accompanied by tagunggu' performances. These continue throughout the night in the house or on the jetty and can feature a solo dancer or a pair. Unlike ritual dance, where the spirit medium wears plain black trousers and top, dancers in these celebrations are attired in bright, colourful costumes for special occasions.

A female dancer sometimes wears the narrow-sleeved blouse badjud alal bimbang, which features a butterfly-shaped collar decorated with manik-manik or strands of small beads, with the skirt called hoos or siyal and a sash or sablay. As in the bridal costume, she might also wear a jabbang (crown) headdress, and curved brass fingercaps or salingkuku. A male dancer may wear the narrow-legged tinanjak costume, in which the black top and trousers are decorated with batawi or gold buttons, antuwilas or gold lace, and manik beading. As in the ritual costume, the 
porong headcloth and kandit belt may be of matching textiles. Igal performed in nonritual social gatherings in the village demonstrates the virtuosity of the dancer and his or her slow skilful interaction with the fast music of the tagunggu' ensemble. It also reflects the distinctive styles of the family groups involved. Igal in this context is always spontaneous. The dancer is naturally drawn to the sound of the tagunggu' as it performs various pieces in its repertoire. The interaction and skilful concentration of dancer and musicians in this non-ritual setting are as intense as in the trance state of the ritual context (Pugh-Kitingan, John Baptist, \& Hussin, 2012, pp. 87-97).

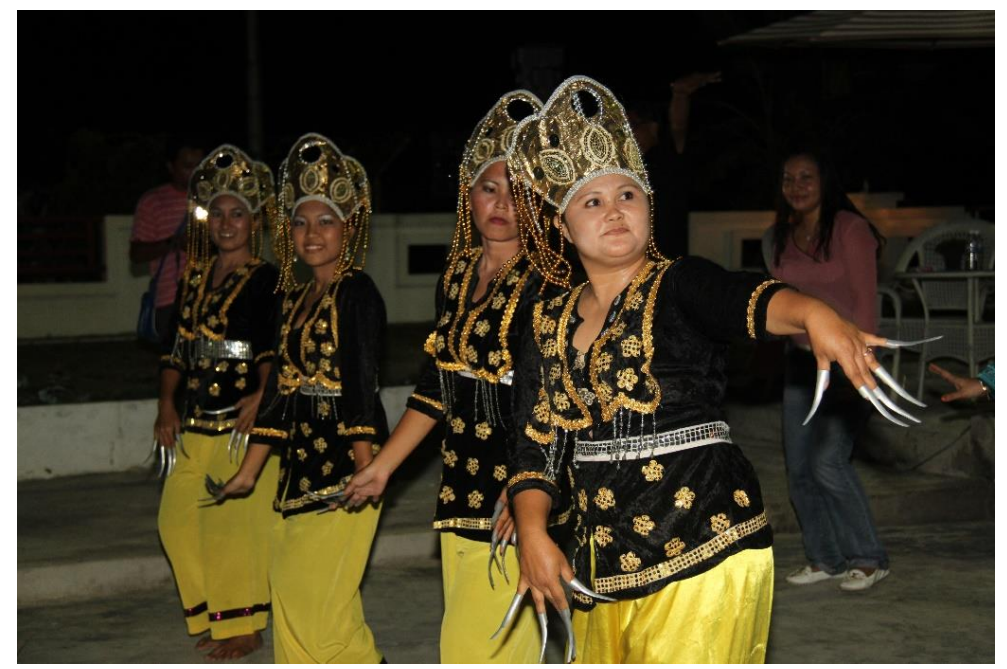

Figure 5: Igal

(Source: Hanafi Hussin)

In the result of the development of the tourism industry in Semporna, the State Government of Sabah has sponsored the annual Regatta Lepa since 1994. Such developments have changed the cultural landscape of the Bajau of Semporna and has brought changes to the traditional styles and contexts of igal performance. The boats are decorated as for Bajau Laut wedding celebrations, with large sambulayang jellyfish-shaped sails and panji-panji pennants. A tagunggu' ensemble plays inside each boat, and alone igal dancer performs on the prow wearing colourful decorated costume and headgear. Nowadays, this festival event also includes the Ratu Igal or "Dance Queen", a competition for young women who perform igal. Each dancer wears the ceremonial wedding costume, featuring the badjud alal bimbang blouse with beaded butterfly collar, silken hoos or siyal skirt, jabbang headdress, and salingkuku fingercaps. The girls try to outdo each other in costume and gaudy decoration. Clothing is often made from modern synthetic fabrics in garish colours and decorated with plastic sequins. This competition is a very popular highlight of the Regatta Lepa Festival. Entrants are awarded points not only on their costumes, but 
also on their dancing abilities, and the Queen is selected for her skill in performing igal. The contemporary cultural and political setting enable igal music and dance sustain and maintain among current generation, young and old generation. It also shows that the continuity of the musicscape and dancescape of Bajau as tools for enriching and enhancing the Bajau identity.

\section{Critical aspects: Musicscape, dancescape and continuity of Bajau identity}

Current development with improvement in sound and technology, the Bajau soundscape and musicscape are also ventured into techno sound which the traditional sound and music transmit into the modern concept of performance, modern popular Bajau music and dance. These groups are often organized under various local cultural associations or sponsors, and dancers and musicians can be drawn from several places, not just one village, and occasionally from different dialect groups. The organization of such a performance group necessitates conformity to standard requirements in terms of costume, dance style and also musical repertoire. The preservation and enculturation of family traditions is no longer a consideration in this context. Neither is the spontaneous demonstration of dancing skill. Rather, the emphasis is on fashion and choreographed conformity, and a desire to please the assumed whims of the audience that increasingly includes foreign tourists.

The exchange of ritual space in the home or ceremonial space on the jetty for large stages supported by elaborate electrical lighting and sound systems has encouraged the use of electrical band instruments to accompany so-called "traditional" dance. While the tagunggu' ensemble is still widely played in the villages, modern bands of electric keyboards electrified guitars and western drum sets, and their diatonic band music proliferates in the staged concerts of the Regatta season in Semporna town (the electric keyboard or organ is also beginning to encroach into traditional wedding celebrations). There is also a marked tendency for the dancers to be mainly young women, while the musicians are nearly always men.

Sincere efforts by the state government to develop igal and tagunggu' as cultural icons of the Semporna Bajau, for the tourism industry in the area, have in fact led to a distortion of tradition and the development of new regimented styles of dance, music and costume. Nevertheless, igal continues as a distinctive characteristic of Semporna Bajau culture.

\section{Conclusion}

The article reviewed Sama-Bajau's igal-music/soundscapes and igal-dancescape in ritual performances that meant to connect and balance the spiritual and physical worlds. Sound/musicscape and dancescape constituted the desired social, cultural and ritualistic environment in which physical actors on the beat of drums (sounds) 
called, met, invited to eat fresh food, and amused them or overpowered them in case any of these had become harmful to the community or its members.

In the ritual, the dancer performed unique dancescapes on the sound/musicscape. The actors and audiences knew the specific context (Smith, 1994) in which the two scapes (music and dance) coherently interacted in the ritual performance. These worked together to guide the audience on how to manage the relationship with the unseen/spiritual world and how to live life without sins, which often caused anger among spirits. Music from the drums and other instruments combined with sounds from footsteps (dancescapes); it created melody and rhythm which represented (or symbolized) the unseen world. The melody and rhythm had to be followed by the physical worlds through specific body and foot movements so that ties with spiritual world strengthened.

Beyond this traditional role of igal-dancescape and igal-musicscape, Samabajau's ritual performance is subject to influence as Appadurai (1990) envisaged that nothing is permanent to remain the same state but changing) of modern fluids which have influenced the communities, and in somehow changed their traditional dance and music scapes through introduction of modern tools and instruments through many events and festivals. Though the genuinity of the dance and musicscape of the communities have reduced somehow but yet still these scapes are cherished as the identity of the community on both sides of borders and also a great source of balancing the power between the two worlds.

\section{Acknowledgements}

The authors would like to thank and acknowledge the financial support provided by the University of Malaya for the research grants RG155-12SUS, RG212-13SUS \& RU009F-2018. The authors also acknowledge the contributions made by the research participants who patiently took part in this study. This study would not be possible without their assistance.

\section{References}

Albrow, M. (1997). Travelling beyond Local Cultures: Socioscapes in a Global City. In J. Eade (Ed.), Living the Global City: Globalization as a Local Process (pp. 35-52). London: Routledge.

Appadurai, A. (1990). Disjuncture and Difference in the Global Cultural Economy. In M. G. Durham \& D. M. Kellner (Eds.), Media and Cultural Studies: Keyworks (pp. 584-603). Malden: Blackwell Publishing.

Appadurai, A (1996). Modernity at Large: Cultural Dimensions of Globalization. Minneapolis: University of Minnesota Press. 
Bitner, M. J. (1992). Servicescapes: The Impact of Physical Surroundings on Customers and Employees. Journal of Marketing, 56, 57-71.

Blacking, J. (1985). Movement, Dance, Music and the Venda Girls' Initiation Cycle. In P. Spencer (Ed.), Society and the Dance: The Social Anthropology of Process and Performance (pp. 64-91) Cambridge: Cambridge University Press.

Choy, S.-L. (2006, 29 October). Chosen by the Goddess. The Star. Retrieved from https://www.thestar.com.my/data/archives/2013/07/02/16/46/chosen-by-thegoddess/

Cowan, J. K. (1990). Dance and the Body Politic in Northern Greece. Princeton: Princeton University Press.

Di Giovine, M. A. (2009). The Heritage-scape: UNESCO, World Heritage, and Tourism. Plymouth: Lexington Books.

Harper, K., \& Armelagos, G. (2010). The Changing Disease-scape in the Third Epidemiological Transition. International Journal of Environmental Research and Public Health, 7(2), 675-697.

Hussin, H., John Baptist, J., \& Pugh-Kitingan, J. (2018). Enriching the Soundscape and Dancescape of Sabah through Sumazau. JATI-Journal of Southeast Asian Studies, 23(2), 181-2014.

Hussin, H., \& Santamaria, MCM. (2008). Dancing with the Ghost: Experiencing the Pagkanduli Ritual of Sama Dilaut (Bajau Laut) in Sikulan, Tawi-Tawi, Southern, Philippines. JATI-Journal of Southeast Asian Studies, 13, 159-172.

John Baptist, J., \& Regis, P. (2012). Magpa-igal Jin: A Ritual Dance, Linking the Past with the Present among the Sama Dilaut of Sabah. In B. Abel, H. Hussin, \& M. Santamaria (Eds.), Oceans of Sound: Sama Dilaut Performing Arts (pp. 89-104). Hildesheim: OLMS.

Johnson, T. M. (2011). Dancescape: Emotive Creation and Embodied Negotiations of Territory, Belonging, and the Right to the City in Cape Town, South Africa. Doctoral dissertation, Department of Geography, University of North Carolina at Chapel Hill, Chapel Hill, United States of America.

Lull, J. (1985). On the Communicative Properties of Music. Communication Research, 12(3), 363-372.

Nor, M. A. M., \& Hussin, H. (2011). Gendering Dance, Gazing Music: Dance Movements, Healing Rituals and Music Making of Sama Bajau and Sama Dilaut of East Malaysia and Southern Philippines. Journal of Maritime Geopolitics and Culture, 2(1), 103-120.

Nor, M. A. M., \& Hussin, H. (2012a). Celebrations with the Ancestors: Magduwata Ritual of Sama Bajau in Bumbum Island, Semporna, Sabah. In In H. Hussin \& MCM Santamaria (Eds.), Sama Celebrations: Ritual, Music and Dance of Sama Dilaut and Sama Bajau in Southern Philippines and North Borneo (pp. 23-34). Kuala Lumpur : Institute of Ocean and Earth Sciences. 
Nor, M. A. M., \& Hussin, H. (2012b). Mag-Igal and Igal-Jin: Dancing the Spirit of the Ancestors in the Ritual of Magduwata of the Bajau Kubang in Bumbum Island, Semporna, East Malaysia. In E. I. Dunin, A. Giurchescu, \& S. Konczei. Cluj-Napoca (Eds.), From Field to Text $\mathcal{E}$ Dance and Space: Proceedings for the $24^{\text {th }}$ Symposium of the ICTM Study Group on Ethnochoreology (pp. 143-148). ClujNapoca: Romanian Institute for Research on National Minorities.

Nitsiakos, V. (2003). Htizontas to horo kai to hrono [Building time and space]. Athens: Odisseas.

Oakes, S. (2000). The Influence of the Musicscape within Service Environments. Journal of services marketing, 14(7), 539-556.

Oakes, S., \& North, A. C. (2008). Reviewing Congruity Effects in the Service Environment Musicscape. International Journal of Service Industry Management, 19(1), 63-82.

Papakostas, C. (2015). Dancecapes of Dionysus: From Kali Vrisi (Northern Greece) to the Olympics. In A. Shay \& B. Sellers-Young (Eds.), The Oxford Handbook of Dance and Ethnicity. Oxford University Press: Oxford. doi: 10.1093/oxfordhb/9780199754281.013.35

Porteous, J. D., \& Mastin, J. F. (1985). Soundscape. Journal of Architectural and Planning Research, 2(3), 169-186.

Pugh-Kitingan, J., Hussin, H., \& John Baptist, J. (2012). Dance as Ritual, Dance as Celebration-Tradition and Change amongst the Bajau Of Semporna, Sabah. In H. Hussin \& MCM Santamaria (Eds.), Sama Celebrations: Ritual, Music and Dance of Sama Dilaut and Sama Bajau in Southern Philippines and North Borneo (pp. 93-102). Kuala Lumpur : Institute of Ocean and Earth Sciences.

Schulte-Fortkamp, B., \& Kang, J. (2013). Introduction to the special issue on soundscapes. The Journal of the Acoustical Society of America, 134(1), 765-766.

Shepherd, J. (1991). Music as Social Text. Cambridge: Polity Press.

Smith, S. J. (1994). Soundscape. Area, 26(3), 232-240.

Szeto, K. Y. (2010). Calligraphic Kinesthesia in the Dancescape: Lin Hwai-min's Cosmopolitical Consciousness in the Cursive Trilogy. Dance Chronicle, 33(3), 414-441.

Tassanawongwara, C., \& Hussin, H. (2019). Klong Yao and the Performance of Minority Identity in the Siamese Community of Perlis. Malaysian Journal of Music, 8, 1-18.

Wheaton, B. (2004). Introduction: Mapping the Lifestyle Sport-scape. In B. Wheaton (Ed.), Understanding Lifestyle Sport (pp. 13-40). London: Routledge.

Wong, E. P. Y. (2011). An Insider's Guide to the Street Dance Subculture in Singapore. Undergraduate Final Year Project, School of Humanities and Social Sciences, Nanyang Technological University, Singapore.

Date of Received: 15 January 2019 Date of Accepted: 15 February 2019 